\title{
Vitamin D reseptör ekspresyonunun kolorektal kanserlerde evre ile ilişkisi ve prognoz üzerine etkisi
}

\author{
Expression of vitamin D receptor in colorectal cancer staging and its effects on prognosis
}

\author{
(DMehmet Sezgin PEPELER ${ }^{1}$, (DBerna SAVAŞ², (DMerve PAMUKÇUOĞLU1', (DMurat TÖRÜNER ${ }^{3}$, (DHakan AKBULUT ${ }^{4}$ \\ Ankara Bilkent Şehir Hastanesi, ${ }^{1}$ Erişkin Hematoloji Kliniği, Ankara \\ Ankara Üniversitesi Tıp Fakültesi, ${ }^{2}$ Patoloji Anabilim Dalı, ${ }^{3}$ Gastroenteroloji Bilim Dalı, ${ }^{4}$ Tıbbi Onkoloji Bilim Dalı, Ankara
}

\begin{abstract}
Giriş ve Amaç: Kolorektal kanser hücrelerinde vitamin D reseptör ekspresyonunun tespiti ve bu reseptör ekspresyon derecesi ile kolorektal kanser prognoz ve evresinin ilişkisi olup olmadığını tespit etmektir. Gereç ve Yöntem: Çalısmaya 2003-2009 tarihleri arasında Ankara Üniversitesi Tıp Fakültesi Genel Cerrahi Bölümünde opere olmuş, Ankara Üniversitesi Tıp Fakültesi Patoloji Bölümünde kolon ve rektum kanseri tanısı konulup medikal tedavisi aynı üniversitenin Tıbbi Onkoloji Bölümünce yapılan hastalar dahil edilmiştir. Vitamin D reseptörlerinin değerlendirilmesi için seçilen olguların hematoksilen ve eozin kesitleri yeniden değerlendirildi. Vitamin D reseptör tayininde $9 A 7$ immünoglobulin $\mathrm{G} 2 \mathrm{~b}$ monoklonal antikor boyaması kullanıldı. Bulgular: Çalışmaya 64'ü (\%55.7) erkek ve 51'i (\%44.3) kadın olmak üzere toplam 115 hasta alındı. Vitamin D reseptörü pozitif olan hastalarda genel sağ kalım istatistiksel olarak anlamlı olmasa da reseptör negatif olanlara göre daha iyi bulunmuştur. Vitamin D reseptör pozitif olanlarda medyan sağ kalıma ulaşılamamıştır. 5 yıllık sağ kalım $\% 69.4$ oranında saptanmıştır. Vitamin D reseptör negatif olanlarda medyan sağ kalım 60 ay olarak saptanmıştır. 5 yılık sağ kalım \%32 oranında bulunmuştur. Vitamin D reseptör negatif olanlarda 5 yıllık hastalıksız sağ kalım \%56.8 bulunurken, vitamin D reseptör pozitif olanlarda hastalıksız sağ kalım \%43.3 bulunmuştur. Vitamin D reseptör pozitif ve negatif olanlar arasında hastalıksız sağ kalım açısından istatiksel olarak anlamlı fark saptanmamıştır (p: 0.053). Sonuç: Vitamin D reseptör ekspresyonunun kolorektal kanser prognozu üzerine olan etkisinin tek başına anlamlı olmadığı saptanmıştır. Reseptör ekspresyonu dışında reseptör polimorfizminin ve reseptörün etkilediği yolaklarda rol oynayan mutasyonların da prognozu belirlemede etkili olabileceği kanısına varılmıştır.
\end{abstract}

Anahtar kelimeler: Kolorektal karsinom, vitamin D reseptör pozitifliği, immünohistokimya

\section{GíRiş}

İn vitro çalışmalarda, 1,25 dihidroksi-Vitamin D3 [1,25-(OH)2D3]'ün hücre büyümesi üzerine inhibe edici etkisi; özellikle prostat, kolon, safra kesesi, meme malign hücrelerinde ve lösemide gösterilmiştir. Vitamin (Vit) D'nin apopitotik etkisi; MCF-7 meme kanser hücrelerinde, kolon kanser hücrelerinde, prostat kanser hücrelerinde gösterilmiştir. İnsan Vit D reseptörü (VDR) kod sırası ilk kez 1988'de belirlenmiştir. VDR gen kodu 12q14'de bulunmakta olup 8 ekzon bölgesi içermektedir. VDR hedef hücrelerde sitoplazma ve

Iletişim: Mehmet Sezgin PEPELER

Ankara Bilkent Şehir Hastanesi, Erişkin Hematoloji Kliniği, Ankara

Tel: +90 3125526000 • Faks: +903125526000

E-mail: drsezgin44@gmail.com
Background and Aims: The aim of the study was to evaluate the effects of vitamin $D$ receptor expression on the prognosis and staging of colorectal cancer. Materials and Methods: Pathological specimens of 115 patients diagnosed with colorectal cancer were analyzed. Perinuclear vitamin D receptors were immunohistochemically analyzed with 9A7 IgG2b monoclonal antibody. Results: Vitamin D receptor positivity, serosa infiltration, metastatic lymph node involvement, relapse period, and staging relationship was not statistically significant. Survival was found to be better in vitamin D receptor-positive patients than in vitamin D receptor-negative patients; however, the results were not statistically significant. Vitamin $D$ receptor-positive patients could not achieve median survival, but their 5-year survival was found to be 43.3\%. Vitamin D receptor-negative patients achieved a median survival of 60 months, and the 5-year survival was 56.8\%. Survival without disease was not significant based on vitamin $D$ receptor positivity. There was no significant difference in disease-free survival between vitamin $D$ receptor-positive and vitamin $D$ receptor-negative patients $(p=0.053)$. Conclusion: Colorectal cancer prognosis was not affected with vitamin D receptor expression alone. Besides vitamin D receptor expression, receptor polymorphisms and mutations at the routes of receptor affection and investigation of other factors would be beneficial.

Keywords: Colorectal cancer, vitamin D receptor positivity, immunohistochemistry

nükleusda bulunmaktadır. 1,25-(OH)2D3, hücreye serum Vit D bağlayıc protein yardımı ile diffüzyonla girmekte ve VDR'ye bağlanmaktadır. Vit D yüksek afiniteli nükleer reseptöre sahip olup steroid hormon reseptörlerinde bulunan özelliklere sahiptir (1-3). 1,25-(OH)2D'nin VDR bağlanması ile birlikte retinoid $X$ reseptör de (RXR) aktive olmaktadır. $\mathrm{Bu}$ aktivasyon işlemi ile RXR-VDR-ligand kompleksi sitoplazmadan nükleusa geçmektedir (4). Nükleusa geçince bu kompleks gen transkripsiyonunu regüle etmektedir (3). 
Vit $D$ reseptörü antitümöral etkisini aktif metaboliti olan 1,25-(OH)2D3 üzerinden gerçekleştirmektedir. Vit $D$ ve kolorektal kanser (KRK) ile ilgili yapılan çalışmalarda kolonik epitel hücrelerinin 25-hidroksivitamin D3 [25-(OH) Vit D3] ve 1-alfa hidroksilaz eksprese ettikleri bilinmektedir. Vit $D$ reseptörü normal kolonik epitel hücresinde düşük olmasına rağmen poliplerde ve iyi diferansiye tümör hücrelerinde artmaktadır. Vit D KRK gelişimi üzerine etkisini; hücre proliferasyonunu azaltarak, anjiyogenezisi inhibe ederek, hücre diferansiyasyonunu destekleyerek, apopitozisi stimüle ederek göstermektedir (5). 1,25-(OH)2D3, majör etkisini; hücre siklus fazlarından $\mathrm{G} 1 / \mathrm{S}^{\prime} \mathrm{i}$ inhibe ederek göstermektedir. Tümör invazyon ve metastazını inhibe edici etkisini ise serin proteinaz, metalloproteinaz ve anjiyogenezisi inhibe ederek göstermektedir. VDR ve 1,25-(OH)2D3; KRK hücrelerinde proliferatif etkiyi azaltırken diferansiyasyonu arttırmakta ve karsinogenezisi inhibe eden genlerin transkripsiyonunu değiştirmektedir (6). Hücre çalışmaları, 1,25-(OH)2D3'nin VDR'ye, 25-(OH) Vit D2'den 1000 kat daha fazla bağlandığını gösterse de, popülasyon bazlı çalışmalar kanser riski ile ilişkili olan serum metabolitinin 25-(OH) Vit D2 olduğunu göstermiştir. Nedeni ise 1,25-(OH)2D3'in lokal olarak böbrek dışında eks- trarenal olarak CYP27b1 enzimi üzerinden sentezlenmesidir. Bu enzim böbrekte düşük oranda bulunmakta olup; deri, lenf nodları, kolon, pankreas ve adrenal medulla, beyin, plasenta, prostat epitel hücresi, MCF-7 meme kanser hücresinde bol miktarda bulunmaktadır (7-9) (Şekil 1).

Normal hücreler 25-(OH) Vit $D$ tedavisine büyümeyi inhibe ederek etki göstermekteyken, azalmış CYP27b1 aktivitesi olan kanser hücrelerinde bu etki görülmemektedir. CYP27b1 ekspresyonu insan metastatik kolon tümör hücrelerinde bulunmamaktadır (10). Vitamin D metabolitlerinin degredasyonunda görev alan 25 hidroksivitamin D-24 hidroksilaz (CYP24) kanser oluşumunda etkilidir.

Vit D’nin kanserden koruyucu rolü ile doz ilişkisini belirleyen iki durum vardır. Birincisi; yüksek Vit D değerlerinin kanser koruyucu etkisinin olması, olası gelişecek tümör hücresindeki CYP27b1 değerlerine bağlıdır. CYP27b1 değeri düşükse Vit D'nin koruyucu etkisinin olması için daha yüksek dozlarına intiyaç vardır. İkincisi, CYP24 aktivitesinin yükselmesi ve/veya VDR değerlerinin veya sinyalinin azalması durumunda yüksek Vit $D$ değerlerine intiyaç vardır (11). Vit D reseptör yoğunluğu, hiperplastik polip ve erken evre tümör hücrelerinde artmaktayken, geç evrelerdeki tümörlerde azalmaktadır $(12,13)$.

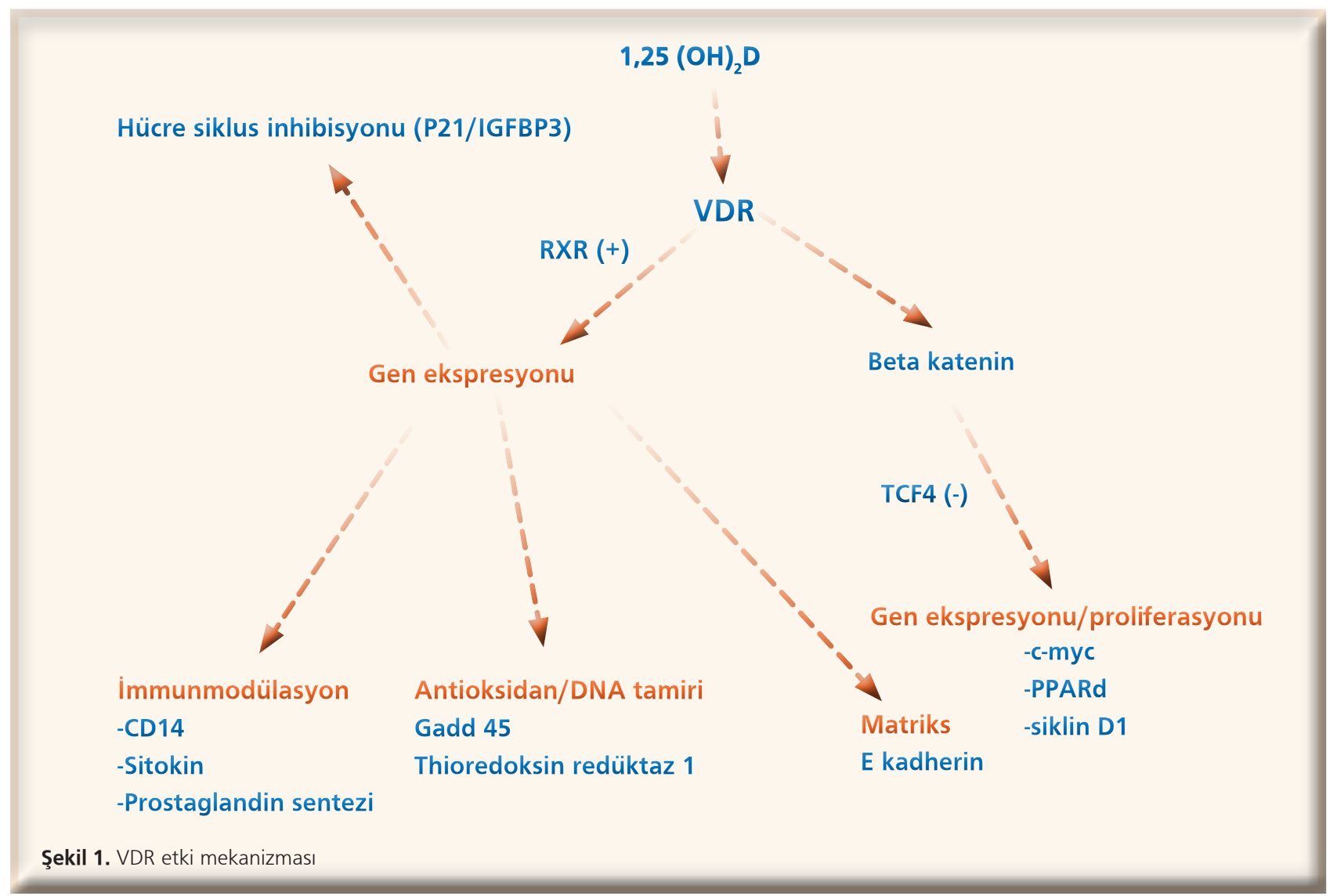

1,25(OH) 2 D: 1,25 dihidroksi Vitamin D. IGF-BP-3: Insülin benzeri büyüme faktörü bağlayıcı protein. VDR: Vitamin D reseptörü. RXR: Retinoid X reseptör. TCF4: Transkripsiyon faktör 4. PPARd: Peroksizom proliferatör ile aktive edilmiş reseptör delta. 
Vit D birçok farklı protoonkogen ve tümör süpresör geni regüle etmektedir. Bunların içinde en önemlisi olan büyüme faktörü hedef yolağında yer alan transforme edici büyüme faktör beta (tumour growth factor-beta: TGF- $\beta$ ) epitelyal hücre proliferasyonunu inhibe etmektedir. Vit D; interferon-gama (IFN- $\gamma$ ) ve interlökin 12'nin (IL-12) negatif regülasyonunu arttırmaktadır. Vit D3 türevleri, P21 ve P27'nin birçok kanser hücresinde ekspresyonunu arttırmaktadır. 1,25-(OH)2D3 protoonkogen olan c-Fos, c-Myc üzerine inhibe edici etki ederek kanser oluşumunu önlemektedir. Yine Vit $D$, programlı hücre ölümünden sorumlu olan $\mathrm{Bcl}-2$ ekspresyonunu azaltıp, bax gen ekspresyonunu arttırmaktadır. 1,25-(OH)2D3, meme, kolon, glioma hücrelerinde apopitozisi indüklemektedir (14).

Vit D'nin yüksek düzeylerinin KRK riskini azaltabileceği desteklenmektedir. 200-400 IU/gün gibi bir düzeyde Vit D içeren tipik diyetler, fark edebilecek yararları gösterebilmek için çok düşük olabilir. Kolon kanser riskinde dikkate değecek şekilde azalma olması için günlük 700-800 IU Vit D alınması gerekmektedir. Koruyucu etki; güneş ışığına maruziyet ile birlikte daha yüksek Vit D düzeyleri ile ortaya çıkabilir. Yapılan prospektif çalışmalarda, sirkülasyondaki 25-(OH) Vit D düzeyi ile; rektal kanser, kolorektal kanser, adenoma arasında zıt ilişkinin olduğu saptanmıştır (15-17). Dünya Sağlık Örgütünün yaptığı bir çalışmada da Vit D plazma düzeyi ile KRK riski arasında ters ilişki olduğu görülmüştür. KRK ve Vit $D$ arasındaki ilişki kesin olmamakla birlikte en az $30 \mathrm{ng} / \mathrm{mL}$ Vit D düzeyi sağlıklı bir durum için gerekmektedir.

\section{GEREÇ ve YÖNTEM}

\section{Vit D Reseptörlerinin Değerlendirilmesi}

Seçilen olguların hematoksilen ve eozin (H-E) kesitleri yeniden değerlendirildi. Bu kesitlerin parafin bloklarından hazırlanan 4 mikron kalınlığındaki kesitler Avidin-biotin peroksidaz tekniği ve "Ventana i-View DAB Detection" kiti kullanılarak, anti-Vitamin D reseptör antikoru (clone: 9A7 IgG2b monoklonal antikoru, Millipore/Almanya) 1:50 dilüsyonda Ventana Benchmark XT immünohistokimya otomatik boyama makinasında boyandı (Resim 1). Antikor immün reaktivitesinin gösterilmesi için kahverengi bir boyanmanın ortaya çıktığı ventana diaminobenzidine (DAB) sistemi kullanıldı. Tümör hücrelerinde perinükleer ve nükleer boyanma pozitif olarak değerlendirildi. Boyanma dağılımı kesitte pozitif olarak boyanan tümör yüzdesi olarak değerlendirildi. Buna göre \%0-5 dağılımı olanlara +, \%6-50 dağılımı olanlara ++, \%51 ve üstü dağılımı olanlara +++ değerleri verildi. Boyanma şiddeti; 0 : negatif, + : zayıf, ++: orta, +++: kuvvetli olmak üzere dörtlü bir skala üzerinden yapıldı. Boyanma şiddeti ve yüzdesine ait değerlerin toplamı toplam skor olarak hesaplandı.

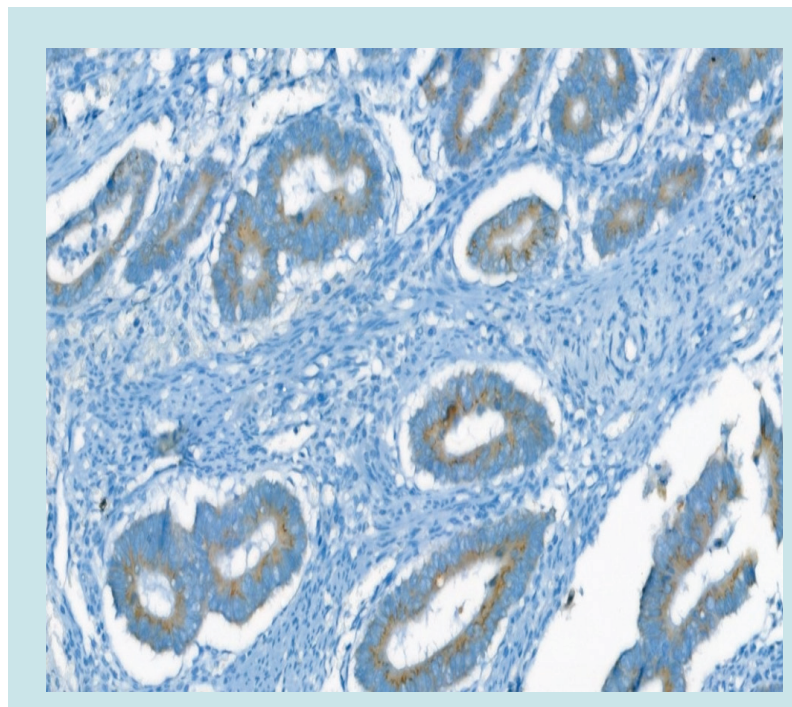

Resim 1. Kolon karsinom, anti-vitamin D boyası ile boyanma (streptavidin-biyotin, $\times 25$ )

\section{BULGULAR}

Çalışmaya 64 (\%55.7) erkek ve 51 (\%44.3) kadın olmak üzere toplam 115 hasta alındı. Ortanca yaş 59 olup yaş dağılımı 28-81 arasında saptandı. 113 hastanın patolojisi adenokarsinom, 2'sinin taşlı yüzük hücreli karsinomdu. Çalışmaya dahil edilenlerden 5 olgu (\%4.3) evre I, 11 olgu (\%9.6) evre II, 71 olgu (\%61.7) evre III, 27 olgu (\%23.5) evre IV olarak saptandı. 1 (\%0.9) hastanın evresi saptanamamıştır (Tablo 4.1). 12 hastanın patolojik preperatlarına ulaşılamadığı için Vit D reseptör durumu hakkında değerlendirme yapılamadı. Patolojik olarak grade değerlendirilmesinde, grade I olgu saptanmadı. Grade II 71 olgu, grade III 29 olgu değerlendirildi. Sekiz olgunun grade değerlendirilmesi parafin bloklarına ulaşılamaması nedeni ile yapılamadı. Patolojik olarak değerlendirmede serozal infiltrasyon 106 olguda (\%92.2) saptandı. Tüm olgular kemoterapi almış olmakla beraber, 19 (\%18.4) olgu ek olarak radyoterapi almıştır. Hastaların demografik özellikleri, patolojik değerlendirme özellikleri ve klinik özellikleri Tablo 1 ve 2'de verilmiştir. Perinükleer Vit D reseptör değerlendirilmesine alınan hastalar, lenf nodu tutulumu açısından değerlendirilmiş ve iki grup arasında istatiksel olarak anlamlı farklılık saptanmamıştır (Tablo 3).

Perinükleer Vit D reseptör değerlendirilmesine alınan 103 hastanın patolojik değerlendirmesinde 96 hastada seroza infiltrasyonu mevcutken, 7 hastada seroza infiltrasyonu saptanmamıştır. Perinükleer Vit D reseptör pozitifliği ile seroza infiltrasyonu arasında istatiksel olarak anlamlı bir fark saptanmamıştır (Tablo 4).

Çalışmaya katılan hastaların retrospektif değerlendirmesinde, toplam 94 hastanın dosyasında hastalık nüksü 
hakkında net bilgiye ulaşıldı. Nüks etme süresi bakımından incelendiğinde, değerlendirilebilen perinükleer Vit D reseptör pozitifliği olan 68 hastanın 40'ında 1 yıl içinde nüks gözlenirken 28 hastada 2 yıl içinde nüks gözlendi. Yine nüks bakımından değerlendirilebilen perinükleer Vit D reseptör negatifliği olan 26 hastanın 18 'inde 1 yı içinde nüks, 8 'inde 2 yıl içinde nüks saptandı (Tablo 5). Çalışmamızda medyan sağ kalım değerine ulaşılamamıştır. 5 yıllık sağ kalım oranı \%61.2 saptanmıştır (Şekil 2).

Vit $D$ reseptörü pozitif olan hastalarda sağ kalım istatistiksel olarak anlamlı olmasa da reseptör negatif olanlara göre daha iyi bulunmuştur. VDR pozitif olanlarda medyan sağ kalıma ulaşılamamıştır. 5 yıllık sağ kalım \%69.4 oranında saptanmışıı. VDR negatif olanlarda medyan sağ kalım 60 ay saptanmıştır. 5 yıllık sağ kalım \%32 oranında bulunmuştur.

Hastalıksız sağ kalım için VDR'e göre anlamlı fark saptanmadı. VDR negatif olanlarda hastalıksız sağ kalım \%56.8 bulunurken VDR pozitif olanlarda \%43.3 bulunmuştur.

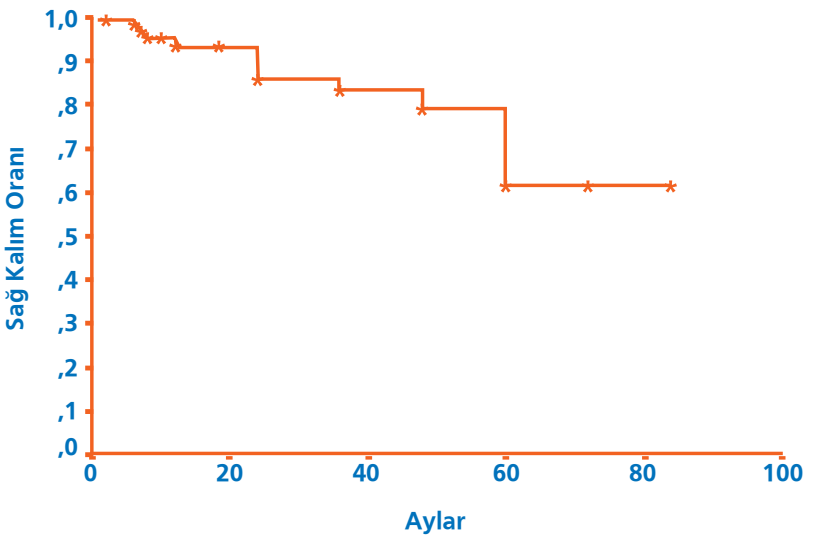

Şekil 2. Genel sağ kalım Kaplan Meier eğrisi

VDR pozitif ve negatif olanlar arasında hastalıksız sağ kalım açısından istatiksel olarak anlamlı fark saptanmamışıı (p:0.053) (Şekil 3).

Tablo 1. Çalışmaya alınan tüm hastaların demografik ve klinik özellikleri

\begin{tabular}{|c|c|c|c|c|c|}
\hline Değişken & Tüm Hastalar (\%) & $\begin{array}{l}\text { Perinükleer } \\
\text { VDR (+) (\%) }\end{array}$ & $\begin{array}{l}\text { Perinükleer } \\
\text { VDR (-) (\%) }\end{array}$ & $\begin{array}{c}\text { Perinükleer VDR } \\
\text { Değerlendirilemeyenler (\%) }\end{array}$ & p \\
\hline Hasta sayısı (\%) & 115 & & & & \\
\hline \multicolumn{6}{|l|}{ Cinsiyet (\%) } \\
\hline Erkek & $64(\% 55.7)$ & $44(\% 68.8)$ & $14(21.9)$ & $6(\% 9.4)$ & 0,541 \\
\hline Kadın & $51(\% 44.3)$ & $30(\% 58.8)$ & $15(\% 29.4)$ & $6(11.8)$ & \\
\hline Yaş (yıl) & $58.5 \pm 10.55$ & $59.9 \pm 9.83$ & $55.93 \pm 11.42$ & $58.58 \pm 10.66$ & 0.530 \\
\hline \multicolumn{6}{|l|}{ Patolojik tanı } \\
\hline Adenokarsinom (kolon) & $86(\% 74.8)$ & $56(\% 65.1)$ & $23(\% 26.7)$ & $7(\% 8.1)$ & 0.480 \\
\hline Adenokarsinom (rektum) & $27(\% 23.5)$ & $17(\% 63)$ & $5(\% 18.5)$ & $5(\% 18.5)$ & \\
\hline Taşlı yüzük hücreli karsinom (kolon) & $2(\% 1.7)$ & $1(\% 50)$ & $1(\% 50)$ & $0(\% 0)$ & \\
\hline \multicolumn{6}{|l|}{ Seroza infiltrasyonu } \\
\hline Var & $106(\% 92.2)$ & $69(\% 65.1)$ & $27(\% 25.5)$ & $10(\% 9.4)$ & 0.480 \\
\hline Yok & $9(\% 7.8)$ & $5(\% 55.6)$ & $2(\% 22.2)$ & $2(\% 22.2)$ & \\
\hline \multicolumn{6}{|l|}{ Patolojik grade } \\
\hline Grade (-) & $8(\% 7)$ & $5(\% 62.5)$ & $2(\% 25)$ & $1(\% 12.5)$ & 0.001 \\
\hline Grade I & $0(\% 0)$ & $0(\% 0)$ & $0(\% 0)$ & $0(\% 0)$ & \\
\hline Grade II & $78(\% 65.2)$ & $58(\% 77.3)$ & $13(\% 17.3)$ & $75(\% 65.2)$ & \\
\hline Grade III & $32(\% 27.8)$ & $14(\% 43.8)$ & $15(\% 46.9)$ & $32(\% 27.8)$ & \\
\hline \multicolumn{6}{|l|}{ Evre } \\
\hline Evre I & $5(\% 4.3)$ & $2(\% 40)$ & $2(\% 40)$ & $1(\% 20)$ & 0.710 \\
\hline Evre II & $11(9.6)$ & $8(\% 72.7)$ & $2(\% 18.2)$ & $1(\% 9.1)$ & \\
\hline Evre III & $71(\% 61.7)$ & $44(\% 62)$ & $18(\% 25.4)$ & $9(\% 12.7)$ & \\
\hline Evre IV & $27(\% 23.5)$ & $20(\% 74.1)$ & $6(\% 22.6)$ & $1(\% 3.7)$ & \\
\hline Evresi bilinmeyen & $1(\% 0.9)$ & & & & \\
\hline
\end{tabular}

VDR: Vitamin D reseptörü 


\begin{tabular}{|c|c|c|c|c|}
\hline Değişken & Tüm Hastalar (\%) & $\begin{array}{c}\text { Perinükleer } \\
\text { VDR (+) }\end{array}$ & $\begin{array}{c}\text { Perinükleer } \\
\text { VDR (-) }\end{array}$ & $\mathbf{p}$ \\
\hline Hasta sayısı (\%) & 103 & & & \\
\hline Cinsiyet (\%) & & & & 0.3 \\
\hline Erkek & $45(\% 43.7)$ & $30(\% 40.5)$ & $15(51.7)$ & \\
\hline Kadın & $58(\% 56.3)$ & $44(59.5)$ & $14(\% 48.3)$ & \\
\hline Yaş (yıl) & $58.5 \pm 10.55$ & $59.9 \pm 9.83$ & $55.93 \pm 11.42$ & 0.53 \\
\hline Patolojik tanı & & & & 0.66 \\
\hline Adenokarsinom (kolon) & $79(\% 76.7)$ & $56(\% 75.7)$ & $23(\% 79.3)$ & \\
\hline Adenokarsinom (rektum) & $22(\% 21.4)$ & $17(\% 23)$ & $5(\% 17.2)$ & \\
\hline Taşlı yüzük hücreli karsinom (kolon) & $2(\% 1.9)$ & $1(\% 1.3)$ & $1(\% 3.5)$ & \\
\hline \multicolumn{5}{|l|}{ Patolojik grade } \\
\hline Grade II & $71(\% 71)$ & $58(\% 80.6)$ & $13(\% 46.4)$ & 0.001 \\
\hline Grade III & $29(\% 29)$ & $14(\% 19.4)$ & $15(\% 53.6)$ & \\
\hline \multicolumn{5}{|l|}{ Evre } \\
\hline Evre I & $4(\% 3.9)$ & $2(\% 2.7)$ & $2(\% 7.1)$ & 0.65 \\
\hline Evre II & $10(\% 9.8)$ & $8(\% 10.8)$ & $2(\% 7.1)$ & \\
\hline Evre III & $62(\% 60.8)$ & $44(\% 59.5)$ & $18(64.3)$ & \\
\hline Evre IV & $26(\% 25.5)$ & $20(\% 27)$ & $6(21.4)$ & \\
\hline Radyoterapi & & & & 0.13 \\
\hline$(+)$ & $19(\% 18.4)$ & $11(\% 14.9)$ & $8(\% 27.6)$ & \\
\hline$(-)$ & $84(\% 81.6)$ & $63(\% 85.1)$ & $21(\% 72.4)$ & \\
\hline
\end{tabular}

VDR: Vitamin D reseptörü

\begin{tabular}{|l|ccc|}
\hline \multicolumn{2}{|c|}{ Tablo 3. Metastatik lenf nodu durumu ile perinükleer vit D reseptör durumu arasındaki ilişki } \\
\hline Metastatik Lenf Nodu Sayısı & Tüm Hastalar & $\begin{array}{c}\text { Perinükleer Vit D Reseptör } \\
\text { Pozitif Olanlar }\end{array}$ & $\begin{array}{c}\text { Perinükleer Vit D } \\
\text { Reseptör Negatif Olanlar }\end{array}$ \\
\hline LN (-) & $43(\% 41,7)$ & $31(\% 41,9)$ & $12(\% 41,4)$ \\
\hline $1-3$ LN (+) & $30(\% 29,1)$ & $24(\% 32,4)$ & $6(\% 20,7)$ \\
\hline 4 ve üzeri LN (+) & $30(\% 29,1)$ & $19(\% 25,7)$ & $11(\% 37,9)$
\end{tabular}

LN: Lenf nodu

Tablo 4. Seroza infiltrasyonu ile perinükleer vit D reseptör durumu arasındaki ilişki

\begin{tabular}{|c|c|c|c|c|}
\hline Seroza İnfiltrasyonu & Tüm Hastalar & $\begin{array}{l}\text { Perinükleer Vit D Reseptör } \\
\text { Pozitif Olanlar }\end{array}$ & $\begin{array}{c}\text { Perinükleer Vit D } \\
\text { Reseptör Negatif Olanlar }\end{array}$ & $p$ \\
\hline Var & $96(\% 93,2)$ & $69(\% 93,2)$ & $27(\% 93,1)$ & 0,98 \\
\hline Yok & $7(\% 6,8)$ & $5(\% 6,8)$ & $2(\% 6,9)$ & \\
\hline
\end{tabular}

Tablo 5. Perinükleer vit D reseptör pozitifliği ile nüks etme süresi arasındaki ilişki

\begin{tabular}{|lccc}
\hline Nüks Etme & Perinükleer Vit D Reseptör Pozitifliği & Perinükleer Vit D Reseptör Negatifliği & p \\
\hline 1. yıl içinde & 40 & 18 & 0,350 \\
\hline 2. yıl içinde & 28 & 8 & \\
\hline
\end{tabular}




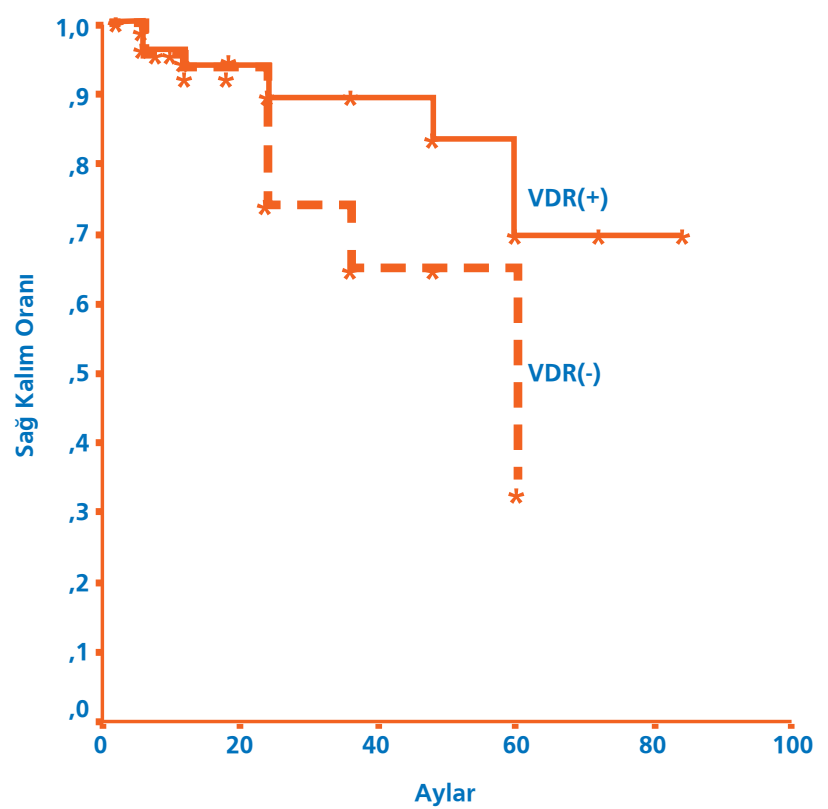

Şekil 3. VDR (+) ve VDR (-) olanlarda sağ kalım eğrileri

\section{TARTIŞMA}

KRK, gastrointestinal sistemin en sık görülen kanseri olup dünyada tüm kanserler içinde akciğer kanserinden sonra ikinci sırada yer almaktadır. 1960'I yıllardan itibaren KRK hastalarının 5 yıllık sağ kalım oranlarında belirgin artışlar izlenmiştir. Sağ kalımdaki bu artışta, daha radikal cerrahi girişimlerin yanı sıra cerrahi öncesi iyi evreleme ve daha iyi patolojik değerlendirme ve adjuvan tedavilerin uygulanması etkili olmuştur.

KRK oluşumunu önlemede koruyucu faktörlerin başında Vit D gelmektedir. Vit D'nin KRK gibi çeşitli kanserlerin görülme riskini azalttığı bilinmektedir. Bu etki; özellikle diyet, deri tipi, coğrafik özellikler, serum 1,25-(OH)2D3 düzeyi ve son yillarda önem kazanan VDR ekpsresyonu ve VDR gen poliformizmine bağılıı.

Illk defa 1980 ylında Vit D'nin antiproliferatif ve diferansiyasyon öncüsü ajan olduğu bulunmuştur. Garland ve arkadaşlarının 1989'da, Cross ve arkadaşlarının 1992'de yaptığı epidemiyolojik çalışmalar sonrası Vit D alımı ile KRK riski arasında ters bir ilişki olduğu gösterilmiştir $(18,19)$. Hulla ve arkadaşlarının 1995 'te yaptığı çalışmalar sonucunda Caco-2 kolon adenokanser hücrelerinde 1,25-(OH)2D3'ün VDR medyatörlüğü eşliğinde büyümeyi inhibe edici etkisinin olduğu gösterilmiştir (20).

VDR, KRK'de erken evre neoplazi durumunda eksprese olmakta, yüksek grade ve metastatik neoplazi durumunda ise eksprese olmamaktadır (21).

VDR, fosfatidilinositol 3 kinaz'a (FI3K) bağlanarak, hücresel proliferasyonu inhibe ederken, diferansiyasyonu arttırmaktadır (22). VDR ekspresyonu yapan hücrelerde; malign transformasyon kazanmak için FI3K ve RAS-MAPK yolağının aktivasyonuna gerek duyulmaktadır (23). Bu yolakların aktivasyon durumu lösemi hücrelerinde ve kolon kanseri hücrelerinde gösterilmiştir (24).

Shoke Kure ve arkadaşlarının yaptığı 619 KRK vakasının katılığı 2 prospektif kohort çalışmasında Kaplan-Meier analizi kullanılarak yapılan değerlendirme sonucunda VDR ekspresyonunun KRK spesifik yaşam süresi üzerinde anlamlı derecede ilişkisinin olmadığı saptanmıştır. Çalışmanın sonucunda VDR'nin asıl etkisini; KRAS ve FIK3CA mutasyonları üzerinden yaptığı ve KRK tedavi ve prognozunda bu iki yolağın dikkate alınması gerektiği belirtilmiştir (25).

Çalışmamızda VDR (+) ve VDR (-) olanlar arasında prognoz açısından önem arz eder fark olmamasının nedeni, VDR (+) olan vakalarda FIK3CA ve KRAS mutasyonlarının olmasından kaynaklanabilir.

1999'da Thomas MG ve arkadaşları yaptıkları bir çalışmada 30 adet kolorektal kanser tanısı olan olguların parafin bloklarında perinükleer Vit $D$ reseptör ekspresyonunu, monoklonal antikorların (9A7 lgG2b) kullanıldığı immünohistokimyasal yöntemle değerlendirmişler. İmmünohistokimyasal yöntem kullanıldığında, kolorektal kanser hücrelerinde Vit $D$ reseptör ekspresyonunun hücresel diferansiyasyon ve hastalık evresi ile bir ilişkisinin olmadığı saptanmıştır (26). VDR'nün tespiti için, radyoligand bağlayıcı teknik kullanıldığında değerlendirmeye alınan kolorektal tümörlerde Vit D reseptör ekspresyonunun azaldığı ve diferansiyasyonuna göre farklılık göstermediği saptanmıştır $(27,28)$. Böylece Vit $D$ reseptör ekspresyonunun klinik sonuçlar açısından iyi bir prognostik değer olabileceğinin şüpheli bulunabileceğini belirtilmiştir.

1990 Ocak ayında J Steroid Biochemistry dergisinde yayınlanan makalede Meggough F ve arkadaşlarının yaptığı çalışmada özofagus, kolon, rektum ve pankreas patoloji spesimenlerinde kanserli doku ve yanındaki normal dokuda nükleer 1,25(OH)2D3 reseptör düzeyi değerlendirilmiş. Çalışmadaki toplam 120 adet kolon adenokarsinom tanısı olan vakalarda yapılan değerlendirmede dekstran kaplı kömür (DKK) tekniği kullanılmış. Normal dokudaki VDR düzeyinin daha yüksek olduğu saptanmış. Düşük reseptör düzeyine ait dokuda malign transformasyonun yüksek olduğu kaydedilmiştir (29). The British Journal of Surgery'de Nisan 1991'de yayınlanan makalede Lointier P ve arkadaşlarının yaptığı 90 adet opere kolon adenokarsinomunda VDR ekspresyonu değerlendirilmiş. Vit D reseptör tayini, DKK tekniği kullanılarak yapılmış. Sonuçta malign transformasyon gösterenlerde reseptör kaybı 
olduğu saptanmış (30). Bizim çalışmamızda da 9A7 lgG2b monoklonal antikorunun kullanıldığı immünohistokimyasal yöntem kullanılarak perinükleer değerlendirme yapıldı. VDR pozitifliği ve negatifliği arasında seroza invazyonu, lenf nodu tutulumu, 5 yıllık yaşam ve hastalıksız sağ kalım açısından istatiksel olarak anlamlı bir fark saptanmadı. Sonucun bu şekilde çıkması, kullanılan boyama tekniğine bağlı olmuş olabilir.

KRK dışında diğer kanserlerde de VDR ile kanser seyri arasındaki ilişki incelenmiş. Meme kanserinde yapılan çaIışmalar sonucunda bazı meme kanser hücrelerinde, Vit $D$ döngüsü ile ilgili enzimlerin fonksiyonlarını değiştirerek veya VDR fonksiyonunu down regüle ederek 1,25 (OH) D'in VDR'e karşı duyarlılı̆ını kaybettiği gösterilmiş. Meme kanseri ile VDR ekspresyonu arasındaki ilişki farelerde bakılmış. VDR ekspresyonu az olan farelerde Vitamin $D$; normal meme bezinde negatif büyüme kontrolüne, anormal duktal morfolojiye, preneoplastik lezyon insidansında artışa yol açtığı görülmüştür (31). Yine meme kanseri üzerine yapılan bir çalışmada hem 1-alfa hidroksilaz hem de VDR, mRNA değerleri ve östrojen reseptör durumunun; histolojik grade, vasküler invazyon durumu, lenf nodu metastazı ile ilişkilerinin olmadığı tespit edilmiş.
Meme kanseri üzerine yapılan bir diğer çalışmada VDR meme kanserinde \%80 bulunmuştur. VDR polimorfizminin meme kanseri prognozu üzerine etkili faktör olduğu tespit edilmiştir (32).

Akciğer kanseri ile yapılan bir çalışmada ileri evre küçük hücreli olmayan akciğer kanserinde Vit D'nin yaşam süresine etkisi saptanmamıştır $(33,34)$.

Renal hücreli karsinom ve VDR ile ilgili yapılan çalışmada, normal böbrek dokusunda VDR ve metabolik yol enzimleri eksprese edilirken malign transformasyonda VDR ve metabolik enzimler kaybolmaktadır (35).

Pek çok durumda, insan kanser hücreleri ve tümörleri, D vitaminin kemo-koruyucu etkilerine karşı dirençli hale gelirler. Bu, VDR aracilı anti-proliferatif genlerin aktivasyonunun baskılanmasından kaynaklanıyor gibi görünmektedir (36).

Sonuç olarak; VDR ekspresyonunun KRK prognozu üzerine olan etkisinin tek başına anlamlı olmadığı saptanmıştır. Reseptör ekspresyonu dışında reseptör polimorfizminin ve reseptörün etkilediği yolaklarda rol oynayan mutasyonların da prognozu belirlemede etkileri olabilir.

\section{KAYNAKLAR}

1. Simboli-Campbell M, Gagnon A, Franks DJ, Welsh J. 1,25-Dihydroxyvitamin D3 translocates protein kinase $C$ beta to nucleus and enhances plasma membrane association of protein kinase $C$ alpha in renal epithelial cells. J Biol Chem 1994;269:3257-64.

2. Diaz GD, Paraskeva Ci Thomas MG, Binderup L, Hague A. Apoptosis is induced by the active metabolite of vitamin D3 and its analogue EB1089 in colorectal adenoma and carcinoma cells: possible implications for prevention and therapy. Cancer Res 2000;60:2304 12.

3. Haussler MR, Whitfield GK, Haussler CA, et al. The nuclear vitamin $D$ receptor: biological and molecular regulatory properties revealed. J Bone Miner Res 1998;13:325-49.

4. Barsony J, Pike W, DeLuca HF, Marx SJ. Immunocytology with microwave-fixed fibroblasts shows 1 alpha,25-dihydroxyvitamin D3-dependent rapid and estrogen-dependent slow reorganization of vitamin D receptors. J Cell Biol 1990;111:2385-95.

5. Fedirko V, Bostiak RM, Long Q, et al. Effects of supplemental vitamin D and calcium on oxidative DNA damage marker in normal colorectal mucosa: a randomized clinical trial. Cancer Epidemiol Biomarkers Prev 2010;19: 280-91.

6. Freedman LP. Transcriptional targets of the vitamin D3 receptor-mediating cell cycle arrest and differentiation. J Nutr 1999;129(2S Suppl):581S-586S.

7. Zehnder D, Bland R, Williams MC, et al. Extrarenal expression of 25-hydroxyvitamin d(3)-1 alpha-hydroxylase. J Clin Endocrinol Metab 2001;86:888-94.

8. Hsu JY, Feldman D, McNeal JE, Peehl DM. Reduced 1alpha-hydroxylase activity in human prostate cancer cells correlates with decreased susceptibility to 25-hydroxyvitamin D3-induced growth inhibition. Cancer Res 2001;61:2852-6.

9. Friedrich $M$, Diesing D, Cordes T, et al. Analysis of 25-hydroxyvitamin D3-1alpha-hydroxylase in normal and malignant breast tissue. Anticancer Res 2006;26:2615-20.

10. Matusiak D, Murillo G, Carroll RE, Mehta RG, Benya RV. Expression of vitamin D receptor and 25-hydroxyvitamin D3-1 \{alpha\}-hydroxylase in normal and malignant human colon. Cancer Epidemiol Biomarkers Prev 2005;14:2370-6.

11. Lointier $\mathrm{P}$, Wargovich MJ, Saez $S$, et al. The role of vitamin D3 in the proliferation of a human colon cancer cell line in vitro. Anticancer Res 1987;7:817-21.

12. Shabahang M, Buras RR, Davodi F, et al. 1,25-Dihydroxyvitamin D3 receptor as a marker of human colon carcinoma cell line differentiation and growth inhibition. Cancer Res 1993;53:3712-8.

13. Sheinin $Y$, Kaserer K, Wrba F, et al. In situ mRNA hybridization analysis and immunolocalization of the vitamin $D$ receptor in normal and carcinomatous human colonic mucosa: relation to epidermal growth factor receptor expression. Virchows Arch 2000;437:5017.

14. Elloul S, Elstrand MB, Nesland JM, et al. Snail, Slug, and Smad-interacting protein 1 as novel parameters of disease aggressiveness in metastatic ovarian and breast carcinoma. Cancer 2005;103:163143.

15. Otani T, Iwasaki M, Sasazuki S; Japan Public Health Center-Based Prospective Study Group. Plasma vitamin D and risk of colorectal cancer: the Japan Public Health Center-Based Prospective Study. $\mathrm{Br}$ J Cancer 2007;97:446-51.

16. Grau MV, Baron JA, Sandler RS, et al. Vitamin D, calcium supplementation, and colorectal adenomas: results of a randomized trial. J Natl Cancer Inst 2003;95:1765-71. 
17. Wactawski-Wnde J, Kotchen JM, Anderson GL, Women's Health Initiative Investigators. Calcium plus vitamin D supplementation and the risk of colorectal cancer. N Engl J Med 2006;354:684-96.

18. Garland CF, Comstock GW, Garland FC, et al. Serum 25-hydroxyvitamin $D$ and colon cancer: eight-year prospective study. Lancet 1989;2:1176-8.

19. Cross HS, Pavelka M, Slavik J, Peterlik M. Growth control of human colon cancer cells by vitamin D and calcium in vitro. J Natl Cancer Inst 1992;84:1355-7.

20. Hulla W, Kallay E, Krugluger W, Peterlik M, Cross HS. Growth control of human colon-adenocarcinoma-derived Caco-2 cells by vitamin-D compounds and extracellular calcium in vitro: relation to c-myc-oncogene and vitamin-D-receptor expression. Int J Cancer 1995;62:711-6.

21. Matusiak D, Murillo G, Carroll RE, Mehta RG, Benya RV. Expression of vitamin D receptor and 25-hydroxyvitamin D3-1 \{alpha\}-hydroxylase in normal and malignant human colon. Cancer Epidemiol Biomarkers Prev 2005;14:2370-6.

22. Deeb KK, Trump DL, Johnson CS. Vitamin D signalling pathways in cancer: potential for anticancer therapeutics. Nat Rev Cancer 2007;7:684-700.

23. Zhang Y, Zhang J, Studzinski GP. AKT pathway is activated by 1, 25-dihydroxyvitamin D3 and participates in its anti-apoptotic effect and cell cycle control in differentiating HL60 cells. Cell Cycle 2006;5:447-51.

24. Hughes PJ, Brown G. 1Alpha,25-dihydroxyvitamin D3-mediated stimulation of steroid sulphatase activity in myeloid leukaemic cell lines requires VDRnuc-mediated activation of the RAS/RAF/ERKMAP kinase signalling pathway. J Cell Biochem 2006;98:590-617.

25. Kure $S$, Nosho $K$, Baba $Y$, et al. Vitamin D receptor expression is associated with PIK3CA and KRAS mutations in colorectal cancer. Cancer Epidemiol Biomarkers Prev 2009;18:2765-72.
26. Thomas MG, Sylvester PA, Newcomb P, Longman RJ. Vitamin D receptor expression in colorectal cancer. J Clin Pathol 1999;52:181-3.

27. Meggouh F, Lointier P, Saez S. Sex steroid and 1,25-dihydroxy vitamin D3 receptors in human colorectal adenocarcinoma and normal mucosa. Cancer Res 1991;5:1227-33.

28. Kane KF, Langman MJ, Williams GR. 1,25-Dihydroxyvitamin D3 and retinoid $X$ receptor expression in human colorectal neoplasms. Gut 1995;36:255-8.

29. Meggouh F, Lointier P, Pezet D, Saez S. Evidence of 1,25-dihydroxyvitamin D3-receptors in human digestive mucosa and carcinoma tissue taken at different levels of digestive tract, in 152 patients. J Steroid Biochem 1990;36:143-7.

30. Lointier P, Meggough F, Dechelotte $P$, et al. 1,25-Dihydroxyvitamin D3 receptors and human colon adenocarcinoma. Br J Surg $1991 ; 78: 435-9$.

31. Welsh J. Vitamin D and breast cancer:insights from animal models. Am J Clin Nutr 2004;80(6 Suppl):1721S-4S.

32. Hines SL1, Jorn HK, Thompson KM, Larson JM. Breast cancer survivors and vitamin D: A review. Nutrition 2010;26:255-62.

33. Heist RS, Zhou W, Wang Z, et al. Circulating 25-hydroxyvitamin D, VDR polymorphisms, and survival in advanced non-small-cell lung cancer. J Clin Oncol 2008;26:5596-602.

34. Blomberg Jensen $M$, Andersen CB, Nielsen JE, et al. Expression of the vitamin D receptor, 25-hydroxylases, 1-hydroxylase and 24-hydroxylase in the human kidney and renal clear cell cancer. J Steroid Biochem Mol Biol 2010;121:376-82.

35. Cross HS, Bises G, Lechner D, Manhardt T, Kállay E. The Vitamin $D$ endocrine system of the gut-its possible role in colorectal cancer prevention. J Steroid Biochem Mol Biol 2005;97:121-8.

36. Byers SW, Rowlands T, Beildeck M, Bong YS. Mechanism of action of vitamin $\mathrm{D}$ and the vitamin $\mathrm{D}$ receptor in colorectal cancer prevention and treatment. Rev Endocr Metab Disord. 2012;13:31-8. 